\title{
E-Learning Development Management With The Schoology Improving Geographic Learning Literation
}

Tengku Muhammad Sahudra

Universitas Samudra, Langsa, Indonesia

e-mail: tengkusahudra@unsam.ac.id

\author{
Alamsyah Taher \\ Universitas Syiah Kuala,Banda Aceh, Indonesia \\ e-mail:taheral876@gmail.com
}

Isthifa Kemal

Universitas Muhammadiyah Sumatera Utara, Padang, Indonesia e-mail: isthifakemal@umsu.ac.id

\author{
A R T I C L E I N F O \\ Article history: \\ 25 December 2020 \\ Received in revised form \\ 01 January 2021 \\ Accepted 25 January 2021 \\ Available online 03 Pebruari \\ 2021 \\ Kata Kunci: \\ Pengembangan, E-learning, \\ Schoology

\section{Keywords:} \\ Development, E-learning, \\ Schoology
}

\begin{abstract}
A B S T R A K
Kurangnya pengembangan media pembelajaran menurunkan minat belajar siswa sehingga mempengaruhi literasi siswa dalam proses pembelajaran. Tujuan dari penelitian ini adalah mengembangkan E-learning dengan schoology untuk meningkatkan literasi pada pembelajaran geografi pada materi flora dan fauna. Jenis penelitian ini adalah penelitian pengembangan. Teknik pengumpulan data dilakukan melalui tiga metode pengumpulan data yaitu observasi, angket dan tes. Teknik analisis data yang digunakan dalam penelitian ini adalah teknik analisis data kuantitatif. Hasil penelitian ini adalah ahli validasi desain produk e-learning dengan schoology yang terdiri dari tiga komponen penilaian validator yang paling dominan yaitu unsur kualitas produk dengan nilai satu validator $52 \%$, dan dua komponen penilaian validator. penilaian validator. $78 \%$, dan hasil uji coba produk dengan nilai 0,42 . \%. Sehingga dapat disimpulkan bahwa E-learning dengan schoology dinyatakan layak digunakan dalam proses pembelajaran dan sangat mudah digunakan berbasis literasi dalam pembelajaran geografi.
\end{abstract}

\begin{abstract}
A B S T R A C T
Lack of development of instructional media reduces student interest in learning so that it affects student literacy in the learning process. The purpose of this research is to develop E-learning with schoology to improve literacy in geography learning in flora and fauna material. This type of research is development research. The data collection technique was carried out through three data collection methods, namely observation, questionnaires and tests. The data analysis technique used in this research is quantitative data analysis techniques. The results of this study are experts in the validation of E-learning product designs with schoology which consists of three components of the validator's most dominant assessment, namely the element of product quality with a value of one validator of $52 \%$, and two components of the validator's assessment. 78\%, and the results of product trials with a value of $0.42 \%$. So it can be concluded that E-learning with schoology is declared suitable for use in the learning process and is very easy to use based on literacy in geography learning.
\end{abstract}

\section{Introduction}

The progress of the 21st-century world is marked by the use of sophisticated technology that affects all aspects of life including education (Kuswanto \& Walusfa, 2017; Wulandari, Sudatha, \& Simamora, 2020). Learning in schools needs to take advantage of technology to keep up with the times. Currently, the generation millennial is very accustomed to using information and communication technology (TIK) (Sari, 2019; Willya, Poluakan, Dikayuana, Wibowo, \& Raharjo, 2019). The demands of this era are a challenge for education. Teachers are required to be able to apply this technology in learning. Primary education to tertiary institutions should have implemented ICT-based learning. But in reality, there are still many schools that have not implemented ICT in the learning process (Anggreni, Wiarta, \& Putra, 2020; Harliawan, 2015). This problem also occurs in one high school. Based on the results of observations and interviews at SMA Negeri 1 Langsa City, a problem was found, namely the lack of ICT-based media that can facilitate students in learning. Based on the results of observations, it was found that students only study in school so that which has an impact on the lack of literacy skills in students. Learning that applies ICT will make it easier for students to learn anywhere and anytime so it is very much needed in this era. 
Based on these problems, the solution that can be used to solve these problems is by developing learning media that can facilitate students in learning. One of the learning media that can facilitate students in learning anywhere and anytime is E-learning. E-learning is a form of learning implementation that utilizes webbased technology (Arifuddin, Suwatra, \& Mahadewi, 2020; Kurtz, Tsimerman, \& Steiner, 2014). The advantages of E-learning are that it can provide flexibility, speed, interactivity, and good visualization (Arifuddin et al., 2020; Zhang, Zhou, Briggs, \& Nunamaker, 2006). E-learning that will be developed using the web schoology. This e-learning accommodates the type of question (question bank) that will be used during the quiz; (3) schoology provides attendance facilities that are used to check student attendance; (4) schoology also provides analytical facilities to view all student activities in each subject, assignment, discussion and other activities that are prepared. E-learning is expected to help students in learning so that it can improve students' literacy skills.

Research conducted by Divayana (2017) obtained the results of research that in general, the level of quality of the use of E-learning at the University of Technology of Indonesia is good. criteria. Second, research conducted by Hignasari \& Supriadi (2020) states that the results of the research are that E-learning research is feasible to be developed and from its application, E-learning can increase the average score of students' mathematics learning outcomes. It can be concluded that E-learning can assist students in learning so that it can improve student learning outcomes. The purpose of this study was to develop E-learning with schoology to improve literacy in geography learning on flora and fauna material at SMA Negeri 1 Langsa City. It is hoped that E-learning with schoology can help students in learning.

\section{Method}

This type of research is research that takes an educational research and development approach (Education Research and Development). Development research is a research method used to produce certain products and test the effectiveness of these products (Awalia, Pamungkas, \& Alamsyah, 2019; Cecep, Mutaqin, \& Pamungkas, 2019; Yuniarni, Sari, \& Atiq, 2020). The product developed is in the form of E-learning with schoology which can be used in the process of developing this product, through expert testing and product testing.

The data collection technique was carried out through three data collection methods, namely observation, questionnaires and tests. The observation method is used to find out the problems that occur at school. The questionnaire method is used to measure the feasibility of the product that has been developed. The test method is used to measure the effectiveness of the developed E-learning. The instrument used to collect data was a questionnaire sheet. The questionnaire sheet is used to collect data regarding reviews from subject content experts, design experts, instructional media, and product trials.

The data analysis technique used in this research is the quantitative data analysis technique, namely by analyzing data on the suitability of the design and learning material on the product obtained from design test experts and material experts who are used to determine the feasibility level of the material. the resulting product. Data on product attractiveness, ease of use and usability were obtained through direct user benefit test results

\section{Result and Discussion}

E-learning with Schoology as a means of learning that is developed and can be said to be of quality if it meets several criteria, namely: (1) a validity test is carried out with a feasibility test. Validation is done by providing an E-learning draft with technological stages from material experts and design experts. Evaluation of module validation includes several components, namely characteristics, quality and language. A recapitulation of the percentage of design validity for each design component can be seen in Figure 1.

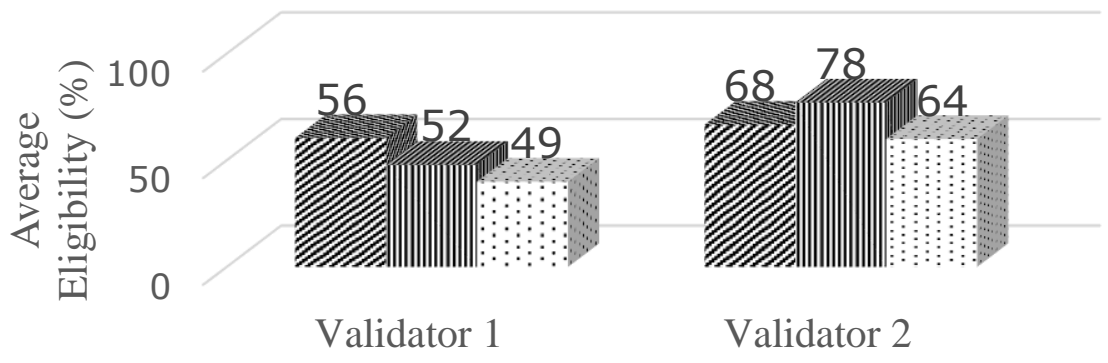

Figure 1. Product Design Validation 
The results of the validation of the E-learning design with schoology in Figure 1 show that the two validators provide a different assessment between the E-learning design and schoology. The highest percentage of design components is found in the quality element components, namely aspects of format, organization, attractiveness, shape and size of letters, spacing, and consistency. The characteristics and language components according to the two validators are still low, so E-learning with schoology is revised according to input and suggestions from the validator. The results of the questionnaire answers are also used as a reference in the revision of E-learning with schoology. E-learning with improved schoology is then given back to the validator for further discussion before testing. The revision is complete if the validator has stated that the E-learning with the developed schoology is valid. The revised E-learning design with schoology is an initial display, an Elearning menu display with schoology and is easy to use. The results of the answers to the E-learning design validation questionnaire with overall schoology can be seen in Figure 2.

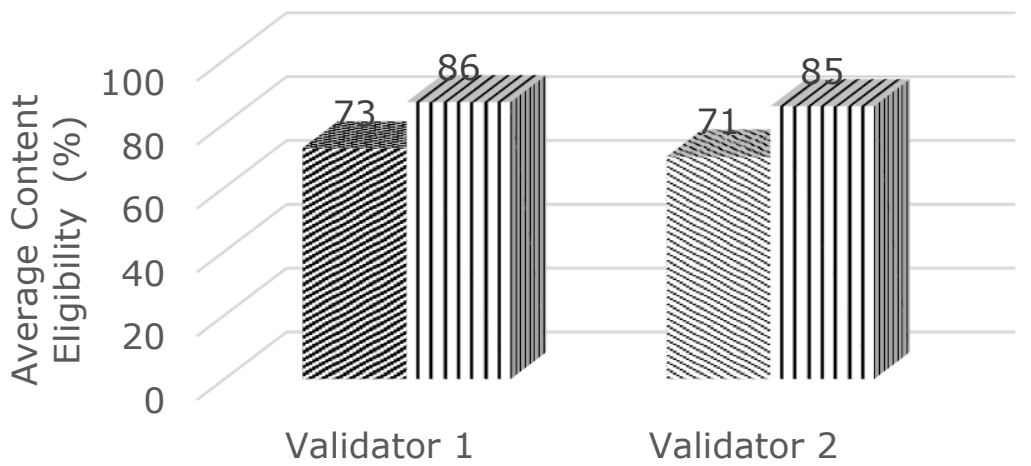

Figure 2. Validate E-learning content with scholoogy

The percentage of material validation before and after revision on average there is an increase in Elearning with schoology by experts. So it can be said that E-learning with schoology can be used in the learning process. Furthermore, practicality testing is carried out by conducting product trials to get information about how easy, interesting, useful and effective E-learning is. This process is carried out with the literacy stage of geography, flora and fauna which consists of three aspects, namely content, process and context, which can be seen in Figure 3.

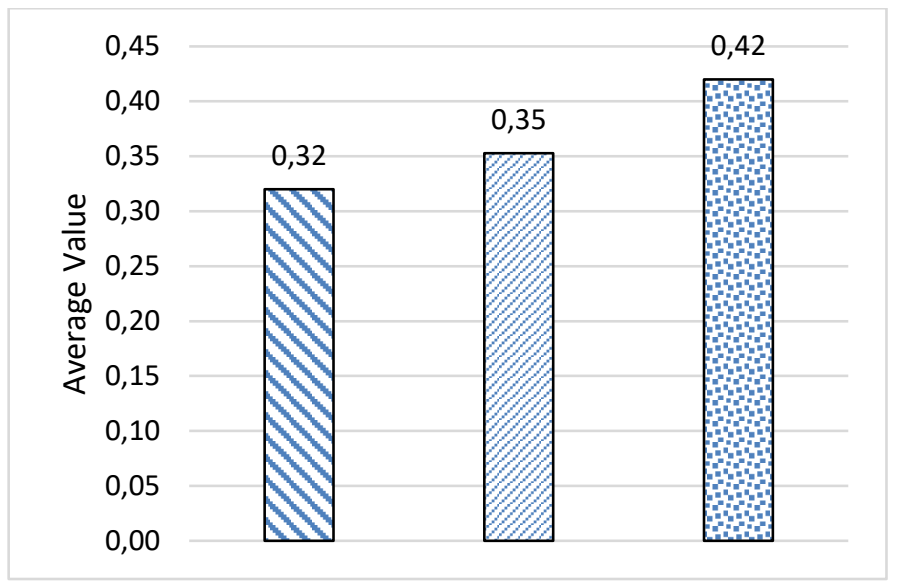

Figure 3. Literacy-Based Practicality Test

The results showed that these three aspects were related to the 5 criteria in the practicality test, namely: (1) very practical; (2) practical; (3) quite practical; (4) less practical; (5) very impractical. The number of statements from the practicality questionnaire was 9 points based on scientific literacy, namely: (1) the content aspect with a value of $0.32 \%$ was declared easy; (2) the process aspect with a value of $0.35 \%$ is declared easy; (3) the context aspect with a value of $0.42 \%$ is stated to be very easy. E-learning with literacy-based Schoology can be used in the learning process due to several factors, namely as follows.

First, E-learning with literacy-based Schoology can be used in the learning process because the $E$ learning developed is very practical, making it easier for students to learn. The e-learning developed is very 
practical because it uses the Schoology application. Some of the advantages of Schoology include: (1) Schoology provides more resource choices than Edmodo; (2) Schoology can accommodate the type of question (question bank) that will be used during the quiz; (3) Schoology provides attendance facilities which are used to check student attendance; (4) Schoology also provides analytics facilities to view all student activities in each course, assignment, discussion and other activities prepared for students (Jayanti \& Rahayuningsih, 2020; Rosy, Ranu, Nugraha, \& Handini, 2018)

Second, E-learning with literacy-based Schoology can be used in the learning process because it can increase student motivation in learning. Attractive learning media will increase student motivation in learning (Herayanti, Habibi, \& Fuaddunazmi, 2017; Wulandari et al., 2020). E-learning is a learning process that is facilitated and supported through the use of information technology and the internet which will motivate students to learn independently and have a commitment to study seriously because the responsibility for learning lies entirely with the students themselves (Irawan, 2018; Putra \& Sudarti, 2015).

Third, E-learning with literacy-based Schoology can be used in the learning process because it can improve student learning outcomes. E-learning media with Schoology can improve student learning outcomes, but technology cannot improve the learning process by itself (Huang, Dedegikas, \& Walls, 2011; Khamparia \& Pandey, 2017). It is better if teachers have to apply methods that make technology impact effective and efficient (Dewi, 2018; Kartowagiran, 2015). One of the activities prepared for students in literacy activities. Literacy is the ability of students to read, write, and communicate through activities that have dynamic and rapid changes which are then widely responded to in social and economic aspects (Izati, Wahyudi, \& Sugiyarti, 2018; Rastati, 2018). Literacy in science subjects can be interpreted as an appreciation of science by increasing the learning components of oneself to have the opportunity to contribute to the environment (Joyo, 2018; Narut \& Supradi, 2019). Science education also aims to improve the competence of students to meet the needs of life in various situations (Marnita, 2013; Nugraha, Suyitno, \& Susilaningsih, 2017).

This research is supported by several relevant studies such as firstly, research conducted by (Divayana, 2017) obtained the results of research that in general, the level of quality of the use of E-learning at the University of Technology of Indonesia is already in good criteria. Second, research conducted by Hignasari \& Supriadi (2020) obtained the results of the research that E-learning research is feasible to be developed and from its application, E-learning can increase the average score of students' mathematics learning outcomes. The three studies conducted by Garad, Al-Ansi, \& Qamari (2021) state that distance learning is positively influenced by the E-learning infrastructure and the cognitive competencies of students, teachers, and administrative staff. It can be concluded that E-learning can be used in learning.

\section{Conclusion}

Based on the results of validation by experts, it can be denied that E-learning with schoology is declared suitable for use in the learning process and is very easy to use based on literacy in learning Geography in flaura and fauna material at SMA Negeri 1 Langsa City.

\section{References}

Anggreni, Wiarta, \& Putra. (2020). Pengaruh Model Pembelajaran ( SAVI ) Berbasis ( TIK ) Terhadap Kompetensi Pengetahuan Matematika. Pedagogi Dan Pembelajaran, 3(1), 15-24. https://doi.org/http://dx.doi.org/10.23887/jp2.v3i1.24357

Arifuddin, Suwatra, \& Mahadewi. (2020). Pengembangan Konten E-learning Berorientasi Pendidikan Karakter Pada Mata Pelajaran Seni Budaya. Jurnal Edutech Undiksha, 8(2). https://doi.org/http://dx.doi.org/10.23887/jeu.v8i2.28942

Awalia, I., Pamungkas, \& Alamsyah. (2019). Pengembangan Media Pembelajaran Animasi Powtoon pada Mata Pelajaran Matematika di Kelas IV. Jurnal Matematika Kreatif-Inovatif, 10(1). https://doi.org/https://doi.org/10.15294/kreano.v10i1.18534

Azimi, Rusilowati, \& Sulhadi. (2017). Pengembangan Media Pembelajaran IPA Berbasis Literasi Sains untuk Siswa Sekolah Dasar. Pancasakti Science Education Journal, 2(2), 145-157. https://doi.org/http://doi.org/10.24905/psej.v2i2.754

Cecep, Mutaqin, \& Pamungkas. (2019). Pengembangan Modul Quick Math Berbasis Mobile Learning sebagai Penunjang Pembelajaran Matematika di SMA. Prisma Sains: Jurnal Pengkajian Ilmu Dan Pembelajaran Matematika Dan IPA IKIP Mataram, 7(2). https://doi.org/https://doi.org/10.33394/jps.v0i0.1761

Dewi, R. S. (2018). Kemampuan Profesional Guru Dan Motivasi Kerja Terhadap Kinerja Mengajar Guru 
Sekolah Dasar. Jurnal Administrasi Pendidikan, 25(1), 150-158. https://doi.org/https://doi.org/10.17509/jap.v25i1.11581

Divayana, D. G. H. (2017). Evaluasi Pemanfaatan E-Learning Menggunakan Model CSE-UCLA. Cakrawala Pendidikan, 2. https://doi.org/https://doi.org/10.21831/cp.v36i2.12853

Garad, A., Al-Ansi, A. M., \& Qamari, I. N. (2021). The Role Of E-Learning Infrastructure And Cognitive Competence In Distance Learning Effectiveness During The Covid-19 Pandemic. Cakrawala Pendidikan, 40(1). https://doi.org/https://doi.org/10.21831/cp.v40i1.33474

Harliawan, H. (2015). Penggunaan Media Pembelajaran Berbasis TIK Untuk Meningkatkan hasil belajar IPS Kelas VIII J SMP Negeri 5 Singaraja. https://doi.org/http://doi.org/10.23887/ekuitas.v3i1.12786

Herayanti, L., Habibi, H., \& Fuaddunazmi, M. (2017). Pengembangan Media Pembelajaran Berbasis Moodle pada Matakuliah Fisika Dasar. Jurnal Cakrawala Pendidikan, 36(2), 210-219. https://doi.org/10.21831/cp.v36i2.13077

Hignasari, L. V., \& Supriadi, M. (2020). Pengembangan E-Learning dengan Metode Self Assessment Untuk Meningkatkan Hasil Belajar Matematika Mahasiswa Universitas Mahendradatta. Jurnal Kependidikan, 6(2). https://doi.org/https://doi.org/10.33394/jk.v6i2.2476

Huang, X., Dedegikas, C., \& Walls, J. (2011). Using multimedia technology to teach Modern Greek Language online in China: Development, implementation and evaluation. European Journal of Open, Distance and E-Learning, 1, 1-9. Retrieved from https://eric.ed.gov/?id=EJ936382

Irawan, H. (2018). Keefektifan E-Learning Sebagai Media Pembelajaran (Studi Evaluasi Model Pembelajaran ELearning Smk Telkom Sandhy Putra Purwokerto). Jurnal Inovasi Teknologi Pendidikan, 5(1), 1-11. https://doi.org/https://doi.org/10.21831/jpv.v3i1.1584

Izati, S. N., Wahyudi, \& Sugiyarti, M. (2018). Project Based Learning Berbasis Literasi untuk Meningkatkan Hasil Belajar Tematik. Jurnal Pendidikan: Teori, Penelitian, Dan Pengembangan, 3(9), 1122-11271127. https://doi.org/10.17977/jptpp.v3i9.11508

Jayanti, R., \& Rahayuningsih, S. (2020). Peran Aplikasi Schoology dalam Pembelajaran Flipped Classroom pada Materi Teks Anekdot. Jurnal Pendidikan Edutama, https://doi.org/https://doi.org/10.30734/jpe.v7i2.933

Joyo, A. (2018). Gerakan Literasi Dalam Pembelajaran Bahasa Indonesia Berbasis Kearifan Lokal Menuju Siswa Berkarakter. Jurnal Kajian Bahasa, Sastra Dan Pengajaran (KIBASP), 1(2). https://doi.org/https://doi.org/10.31539/kibasp.v1i2.193

Kartowagiran, B. (2015). Kinerja Guru Profesional (Guru Pasca Sertifikasi). Jurnal Cakrawala Pendidikan. https://doi.org/10.21831/cp.v3i3.4208

Khamparia, A., \& Pandey, B. (2017). Impact of interactive multimedia in E-learning technologies: Role of multimedia in E-learning. Enhancing Academic Research With Knowledge Management Principles, (April), 199-227. https://doi.org/10.4018/978-1-5225-2489-2.ch007

Kimianti, \& Prasetyo. (2019). Pengembangan E-Modul IPA Berbasis Problem Based Learning Untuk Meningkatkan Literasi Sains Siswa. Kwangsan Jurnal Teknologi Pendidikan, 7(2). https://doi.org/https://doi.org/10.31800/jtp.kw.v7n2.p91--103.

Kurtz, G., Tsimerman, A., \& Steiner, O. (2014). The Flipped Classroom Answer to Future Learning? European Journal of Open, Distance and E-Learning, 17(2). https://doi.org/https://doi.org/10.2478/eurodl-20140027

Kuswanto, J., \& Walusfa, Y. (2017). Pengembangan Multimedia Pembelajaran pada Mata Pelajaran Teknologi Informasi dan Komunikasi Kelas VIII. Innovative Journal of Curriculum and Educational Technology IJCET, 6(2), 58-64. https://doi.org/https://doi.org/10.15294/ijcet.v6i2.19335

Marnita. (2013). Peningkatan Keterampilan Proses Sains Melalui Pembelajaran Kontekstual Pada Mahasiswa Semester I Materi Dinamika. Jurnal Pendidikan Fisika Indonesia, 9(1), 43-52. https://doi.org/10.15294/jpfi.v9i1.2579

Narut, Y. F., \& Supradi, K. (2019). Literasi Sains Peserta Didik dalam Pembelajaran IPA di Indonesia. Jurnal Inovasi Pendidikan Dasar, 3(1), 61-69. 
Nugraha, A. J., Suyitno, H., \& Susilaningsih, E. (2017). Analisis Kemampuan Berpikir Kritis Ditinjau dari Keterampilan Proses Sains dan Motivasi Belajar melalui Model PBL. Journal of Primary Education. https://doi.org/10.15294/jpe.v6i1.14511

Putra, P. D. A., \& Sudarti. (2015). Pengembangan Sistem E-Learning untuk Meningkatkan Keterampilan Berpikir Kritis Mahasiswa Pendidikan Fisika. Jurnal Fisika Indonesia, 19(55), 45-48. https://doi.org/https://doi.org/10.22146/jfi.24373

Rastati, R. (2018). Media Literasi Bagi Digital Natives: Persektif Generasi Z Di Jakarta. Kwangsan: Jurnal Teknologi PendidikanJurnal Teknologi https://doi.org/https://doi.org/10.31800/jtp.kw.v6n1.p60--73

Rosy, B., Ranu, M. E., Nugraha, J., \& Handini, H. T. (2018). Pelatihan Media Pembelajaran Berbasis ELearning, Schoology Bagi Guru SMK Program Keahlian Administrasi Perkantoran Di Kabupaten Jombang Jawa Timur. Jurnal Pemberdayaan Masyarakat Madani, 2(2). https://doi.org/https://doi.org/10.21009/JPMM.002.2.02

Sari, S. (2019). Literasi Media Pada Generasi Milenial Di Era Digital. Jurnal Komunikasi Dan Administrasi Publik, 6(2). https://doi.org/https://doi.org/10.37676/professional.v6i2.943

Suyono, Harsiati, \& Wulandari. (2017). Implementasi Gerakan Literasi Sekolah pada Pembelajaran Tematik di Sekolah Dasar Sekolah Dasar: Kajian Teori dan Praktik Pendidikan. Jurnal Sekolah Dasar Kajian Teori Dan Praktik Pendidikan, 26(2), 116-123. https://doi.org/10.17977/um009v26i22017p116

Warsihna, J. (2016). Meningkatkan Literasi Membaca dan Menulis dengan Teknologi Informasi dan Komunikasi. Kwangsan, 4(2), 67 - 80. https://doi.org/https://doi.org/10.31800/jtp.kw.v4n2.p67--80

Willya, Poluakan, Dikayuana, Wibowo, \& Raharjo. (2019). Generasi Milenial Pada Era Revolusi Industri 4.0. Focus : Jurnal Pekerjaan Sosial, 2(2). https://doi.org/https://doi.org/10.24198/focus.v2i2.26241.

Wulandari, Sudatha, \& Simamora. (2020). Pengembangan Pembelajaran Blended Pada Mata Kuliah Ahara Yoga Semester II di IHDN Denpasar. Jurnal Edutech Undiksha, 8(1), 1-15. https://doi.org/http://dx.doi.org/10.23887/jeu.v8i1.26459

Yuliati, Y. (2017). Literasi sains dalam pembelajaran IPA. Jurnal Cakrawala Pendas, 3(2). https://doi.org/http://dx.doi.org/10.31949/jcp.v3i2.592

Yuniarni, Sari, \& Atiq. (2020). Pengembangan Multimedia Interaktif Video Senam Animasi Berbasis Budaya Khas Kalimantan Barat. Jurnal Obsesi: Jurnal Pendidikan Anak Usia Dini, 4(1). https://doi.org/https://doi.org/10.31004/obsesi.v4i1.331

Zhang, D., Zhou, L., Briggs, R. O., \& Nunamaker, J. F. (2006). Instructional video in e-learning: Assessing the impact of interactive video on learning effectiveness. Information and Management, 43(1), 15-27. https://doi.org/10.1016/j.im.2005.01.004 